\title{
TIDAL INFLUENCE ON SURF ZONE ICHTHYOFAUNA STRUCTURE AT THREE SANDY BEACHES, SOUTHEASTERN BRAZIL*
}

\author{
Luiz Ricardo Gaelzer ${ }^{1,2}$ and Ilana R. Zalmon ${ }^{2}$
}

${ }^{1}$ Instituto de Estudos do Mar Alte Paulo Moreira - Departamento de Oceanografia (Rua Kioto, 253, Praia dos Anjos, 28915-160 Arraial do Cabo, RJ, Brasil)

gaelzermar@terra.com.br

${ }^{2}$ Universidade Estadual do Norte Fluminense - Laboratório de Ciências Ambientais (Av. Alberto Lamego, 2000, Horto, 28013-602 Campos dos Goytacazes, RJ, Brasil) ilana@uenf.br

\section{A B S T R A C T}

Natural assemblages show large variability at multiple scales in space and time as a consequence of several abiotic and biotic factors. This study was conducted in the surf zone of Arraial do Cabo ( $\left.22^{\circ} 58^{\prime} \mathrm{S}, 42^{\circ} 01^{\prime} \mathrm{W}\right)$ and tested the hypothesis that the ichthyofauna composition and structure differ according to the tidal variation at three beaches with different morphodynamic characteristics. From September 2001 to August 2002 three monthly hauls were carried out at each beach during high $(\mathrm{N}=6)$ and low tide $(\mathrm{N}=6)$ with a beach seine ( $25 \mathrm{~m}$ length, 2,50 m height, $10 \mathrm{~mm}$ mesh). At Praia Grande and Prainha beaches, the number of species and individuals was higher during low tide. Also, CPUE (grams) at Praia Grande and Prainha was higher during high tide indicating a movement of many benthivore and piscivore species into the intertidal zone, due to the greater food availability. The fish community structure differed between Prainha and Praia Grande according to the tide in relation to fish biomass, which was higher at high tide, except for Praia dos Anjos (low tide) partially supporting the initial hypotheses. However, the number of individuals and species richness and diversity were higher during low tide, different from the proposed statement, as a reflex of juvenile individuals' abundance.

\section{RES UMO}

Comunidades de peixes sofrem grande variabilidade em escala espacial e temporal em conseqüência de vários fatores abióticos e bióticos. Este estudo foi realizado na zona de arrebentação em Arraial do Cabo $\left(22^{\circ} 58^{\prime} \mathrm{S}\right.$, $\left.42^{\circ} 01^{\prime} \mathrm{W}\right)$ e testada a hipótese de que a composição e a estrutura da ictiofauna difere de acordo com a variação de maré em três praias com características morfodinâmicas distintas. De setembro/2001 a agosto/2002 foram realizados três arrastos mensais em três pontos de cada praia nos períodos de maré baixa $(\mathrm{N}=6)$ e alta $(\mathrm{N}=6)$, através de uma rede do tipo picaré (beach seine) com $25 \mathrm{~m}$ de comprimento por 2,50 m de altura e malha de $10 \mathrm{~mm}$. Na Praia Grande e Prainha, o número de espécies e indivíduos foi superior em maré baixa. Já a CPUE (grama) na Praia Grande e Prainha foi superior na maré alta, indicando um movimento de muitas espécies bentívoras e piscívoras para a zona entremarés em maré cheias, devido à maior disponibilidade de alimento. A estrutura da comunidade de peixes na zona de arrebentação, Praia Grande e Prainha diferiu em função da maré com relação à biomassa de peixes capturados, superior no período de maré alta, exceto na Praia dos Anjos (maré baixa) confirmando parcialmente a hipótese inicial. Já o número de indivíduos, a riqueza e a diversidade de espécies foi superior na maré baixa, diferente do proposto, reflexo da grande abundância de indivíduos juvenis.

Descriptors: Ichthyofauna, Surf zone, Community structure, Tidal variation.

Descritores: Ictiofauna, Zona de arrebentação, Estrutura de comunidade, Variação de maré.

\section{INTRODUCTION}

Marine organisms distribution is determined by a series of complex responses in relation to the biological as well as to the physical characteristics of the environment. Those responses allow habitat selection, which offers the best combination of a great potential for growth and reproduction with the lowest mortality risk (GIBSON et al., 1993). However several species move from one habitat to another in different temporal scales. Coastal habitats, though, do not

(*) Paper presented at the $1^{\text {st }}$ Brazilian Congress of Marine Biology, on 15-19 May. Rio de Janeiro, Brazil. 2006. remain constant, varying regularly on a daily and seasonal basis (GIBSON et al., 1996).

In coastal waters, the aquatic species are subjected to behavioral changes caused by tides whose effects are generally intense in the meso and shallow infralitoral regions. The fish species which inhabit such regions use different strategies to deal with tidal variation in adaptation to the habitat (BROWN; McLACHLAN, 1990), mainly associated with feeding and avoidance of adverse environmental conditions and predators, causing complex migration patterns during tide periods (BURROWS et al., 1994; GIBSON et al., 1998). 
Day and night tidal variations cause an oscillation in environmental factors of ecological interest (MARGALEF, 1986) influencing the relative abundance of certain fish species (CLARK et al., 1996).

The data obtained over six years of surf zone research at Arraial do Cabo, Southeastern Rio de Janeiro State (GAELZER; ZALMON, 2003，2006) show and highlight the importance of this environment for the coastal fish species with the aim of generating projects for preservation and conservation, as this is an environmental protection area. Bennett and Attwood (1993) and Polunin and Roberts (1993) emphasize the importance of these preserved areas in the maintenance and rehabilitation of fish stocks of the nearby communities that may contribute economically to the fishery through its nursery function, attracting young individual (recruitment) of economically valuable species.

The present study aims to investigate the tidal influence on the fish community structure of the surf zone at three beaches of Arraial do Cabo, Rio de Janeiro. The hypothesis to be tested is that the ichthyofauna composition and structure at Praia dos Anjos, Praia Grande and Prainha beaches differs according to tidal variation. Higher values of richness, species diversity and number of individuals and biomass are expected during high tide due to the approaching of larger individuals to the shallower zones due to higher food availability.

\section{StUdy AREA}

The district of Arraial do Cabo is situated between the coordinates $22^{\circ} 58^{\prime} \mathrm{S}$ and $42^{\circ} 01^{\prime} \mathrm{W}$, representing a singular spot in the Brazilian coast due to the change of orientation of the coast from NorthSouth to East-West (VALENTIN, 1984). Although it is located in a tropical region, the study area has a transitional climate, between tropical and subtropical. The average annual air temperature varies from 21 to $26^{\circ} \mathrm{C}$ (YONESHIGUE, 1985).

Three beaches were selected with distinct morphodynamic characteristics: Praia Grande (exposed), Praia dos Anjos (sheltered) and Prainha (intermediate wave exposure) (Fig. 1).

\section{Material AND Methods}

The biological sampling was carried out monthly from September/2001 to August/2002 with a beach seine $25 \mathrm{~m}$ long, $2.50 \mathrm{~m}$ high and $10 \mathrm{~mm}$ opposed nodes mesh. Twelve monthly hauls were carried out on each beach no deeper than $1.50 \mathrm{~m}$ at three sites of each beach, spaced $300 \mathrm{~m}$ apart. Each haul covered $100 \mathrm{~m}$ so as to get uniform samples. At each site of the beach, two hauls were done parallel to the coast during high tide and two more during low tide, totalling six samples according to tide variation at each beach.

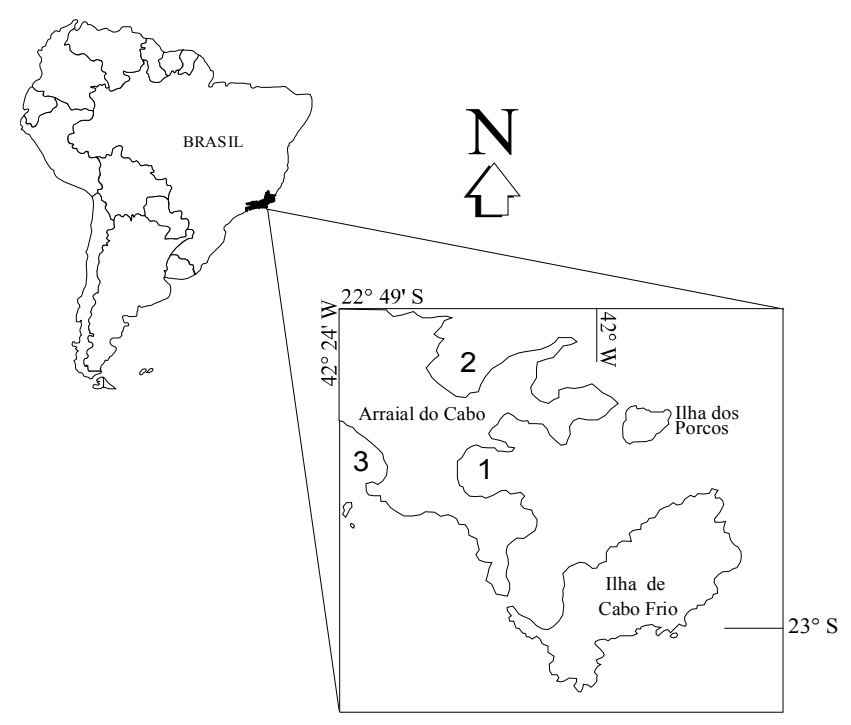

Fig. 1. Location of the studied beaches at Arraial do Cabo, southeastern Rio de Janeiro (1 - Praia dos Anjos beach, 2 - Prainha beach, 3 - Praia Grande beach). 
Fish were identified according to Figueiredo and Menezes (1978, 1980, 2000), Menezes and Figueiredo (1980, 1985) and Cervigón et al. (1993).

The index of species relative abundance was obtained by the Capture per Unit Effort (CPUE) in number (individuals/haul) and weight ( $\mathrm{g} / \mathrm{haul}$ ). Variations in fish community structure and composition were detected by Margalef's richness index, Shannon's diversity (number of individuals) and Simpson's dominance (number of individuals). Fish assemblage's differences between tides at each beach were determined by test $t$ - Student. Average monthly values were previously $\log$ transformed, testing both normality and homocedasticity. The comparative analysis of the fish assemblages at different tides and months included a Non-Metric Dimensional Scaling - MDS based on CPUE per individuals with Bray-Curtis similarity coefficient. The adequacy of the sample configuration in the MDS analysis was obtained by the stress results. Stress values under 0.05 give an excellent representation with no probability of misinterpretation (CLARKE; WARWICK, 2001). The similarity matrix included the species, which contributed with at least $25 \%$ of the samplings. The data were fourth root transformed to diminish the influence of the most abundant species (MUNIZ, 2003). ANOSIM test (one way) was carried out to evaluate the significance of the groups represented in the MDS. The similarity matrix included the fish CPUE (inds/haul) at each beach on each month during high tide and low tide separately. The six samples from each beach at each month were treated as replicates to increase the permutation possibilities and the test power (CLARKE; WARWICK, 2001). The ANOSIM results (R) vary from -1 to +1 . Values equal to +1 occur when all replicates in the groups are more similar among themselves than any replicate of different groups.

The seasons of the studied year are referred as spring (September-October-November), summer (December-January-February), autumn (March-AprilMay) and winter (June-July-August).

\section{Results}

\section{Praia dos Anjos Beach}

The catches at low tide included 44 species, which contributed with $57 \%$ of the total of individuals and biomass; 13 species were exclusive $(30 \%)$. The most representative families were Carangidae (six species), Haemulidae and Sciaenidae (four species each). The dominant species at low tide were Harengula clupeola (52\%), Trachinotus carolinus (18\%), Dactylopterus volitans (7\%) and Umbrina

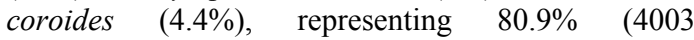

individuals) of total catch (4950 individuals). In relation to biomass values, the dominant species with $72 \%$ (33044g) of total weight caught (46016 g) were H. clupeola (32\%), T. carolinus (10.3\%), Dactylopterus volitans (9.0\%), Albula vulpes (7.7\%) and Eucinostomus argenteus (7.6\%). Species registered at both tide periods are listed in Table 1 .

At high tide 38 species contributed with $43 \%$ of total individuals and biomass (Table 1). The families Carangidae (six species), Sciaenidae, Mugilidae and Clupeidae (three species) were most representative. The five most captured species; representing $83 \%$ (3155 individuals) of total catch (3801 individuals) were $H$. clupeola $(38.6 \%), T$. carolinus $(25.3 \%)$, E. argenteus $(8.1 \%)$, Umbrina coroides $(5.9 \%)$ and Sardinella janeiro $(5.1 \%)$. The species $H$. clupeola (23.6\%), T. carolinus (15.6\%), Trachinotus goodei $(9.8 \%), U$. coroides $(9.6 \%)$ and $E$. argenteus $(8.4 \%)$ had the highest biomass, representing $67 \%$ (24034 g) of total weight (35791 g).

A similar temporal pattern was recorded for the average number of species at low and high tide, with a tendency to higher values during summer and fall (Fig.2a). A higher number of species was generally observed at high tide, but significant differences $(p \leq 0.05)$ between the tides occurred only in November/01 $(p=0.007)$. The highest captures of individuals were observed at low tide, mainly in January/02 $(p=0.04)$ and April/02 $(p=0.03)$, with values two to five times higher, respectively (Fig. 2b). This difference was due to the great number of individuals of Harengula clupeola. In relation to weight $(\mathrm{g} / \mathrm{haul})$, a similar temporal variation was generally observed for low and high tides, significantly different in April/02 $(p=0.04)$, with CPUE value four times higher at low tide (Fig. 2c).

The richness index values were very similar in both periods (without significant differences $-p \leq$ 0.05 ), generally lower in winter (Figure 2d). The diversity (H') showed significant differences $(p \leq$ 0.05 ) between tides in November/01 with a similar temporal variation (Fig. 2e). The dominance showed a similar temporal pattern between tides. Significant difference $(p \leq 0.05)$ occurred only in August/02 (0.039), with higher values at high tide (Fig. 2f).

The MDS ordination analysis related to the CPUE (number of individuals/hauls) at low and high tides in the studied months did not reveal the formation of well-defined groups related to the tide (Fig. 3), but one including the winter months (June, July and August). Months/tides were joined in the plotting of the two first dimensions with a stress of 0.15 , indicating that the similarities are adequately represented by the distances in the chart (Fig. 3). The ANOSIM showed a significant difference between the groups $(\mathrm{R}=0.54$, p: $0.1 \%)$. 
Table 1. Total number of individuals (n) and weight (g) of fish species in Praia dos Anjos beach in low and high tide (September/01 to August/02).

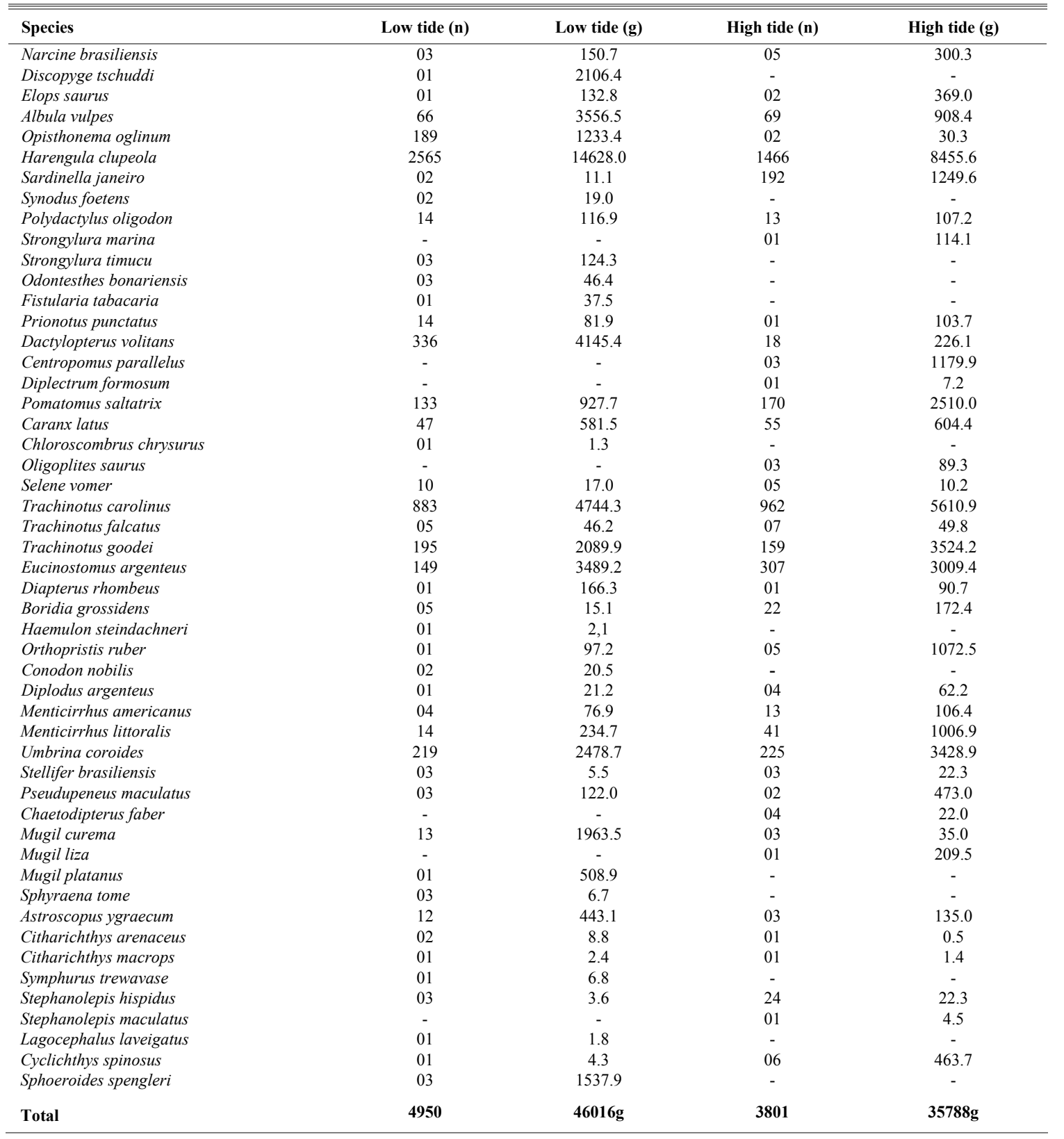

\section{Praia Grande Beach}

During the low tide 18 species were caught, contributing with $52 \%$ of the total individuals and $49 \%$ of the biomass (Table 2); five species were exclusive (28\%). The families most representative were Sciaenidae and Mugilidae (three species each) and Clupeidae (two species). The species Dactylopterus volitans (42.4\%), Harengula clupeola (20\%), Pomatomus saltatrix (15.9\%), Trachinotus carolinus (12\%) and Sardinella janeiro (3.5\%) totalled $94 \%$ of the captures (1343 individuals). The remaining $7 \%$ (85 individuals) corresponded to 13 species. 
a

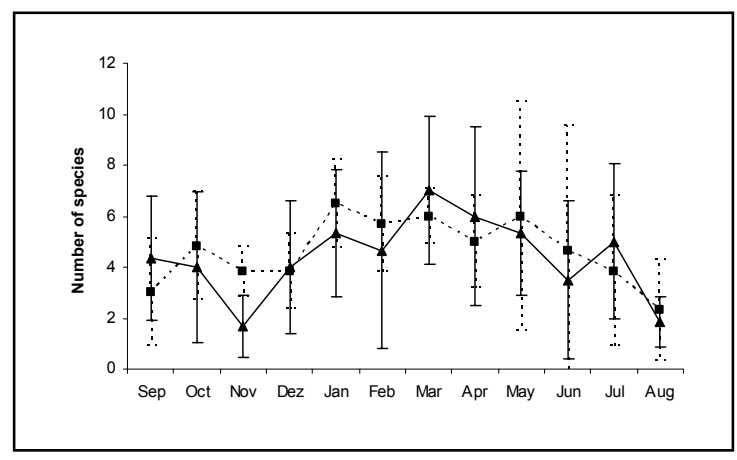

C

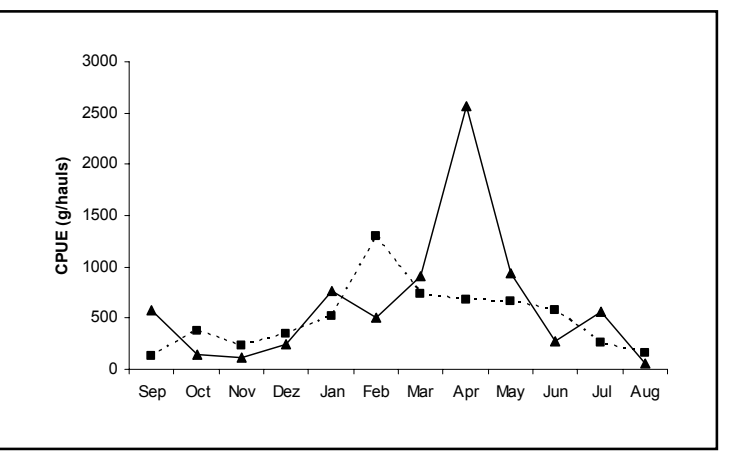

e

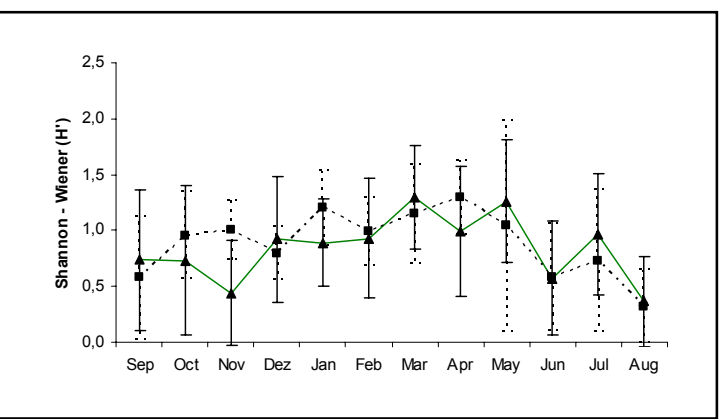

b

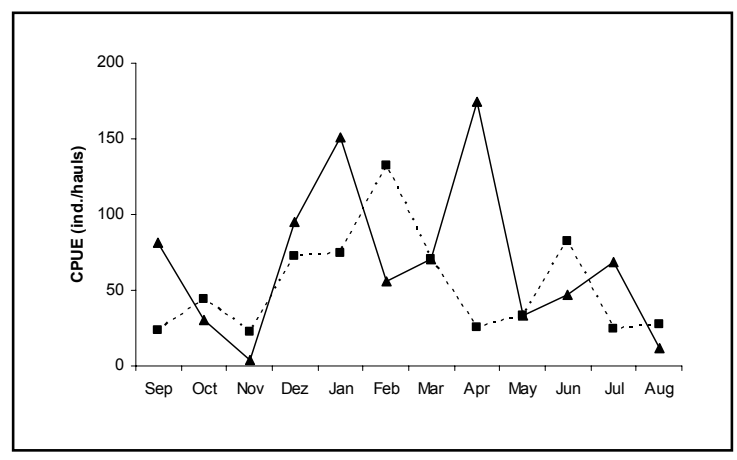

d

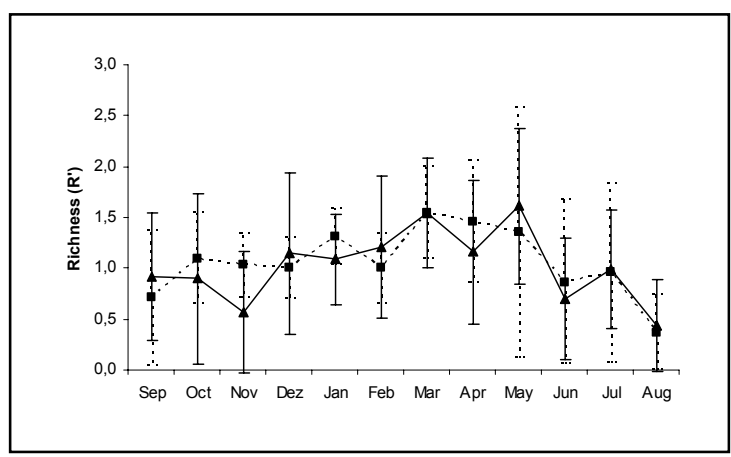

f

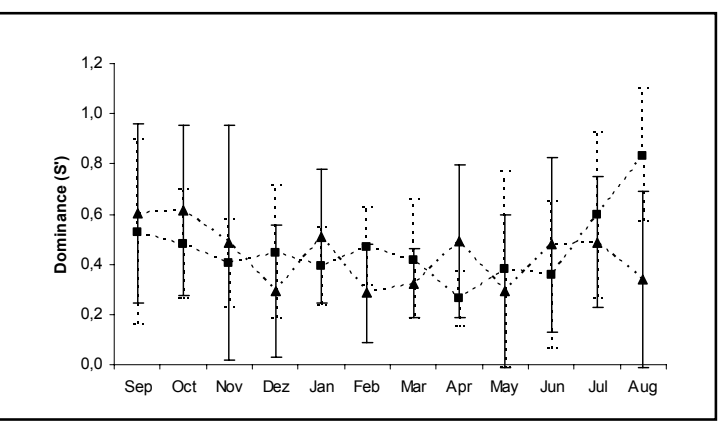

Fig. 2. Temporal variation of average species numbers (a), CPUE ((individuals/haul) (b), CPUE (grams/haul) (c), Margalef's richness (d), Shannon's diversity (e) and Simpson's dominance (f) at low ( $\boldsymbol{\Delta})$ and high ( $\mathbf{a})$ tides at Praia dos Anjos beach (September/01 to Agust/02). 


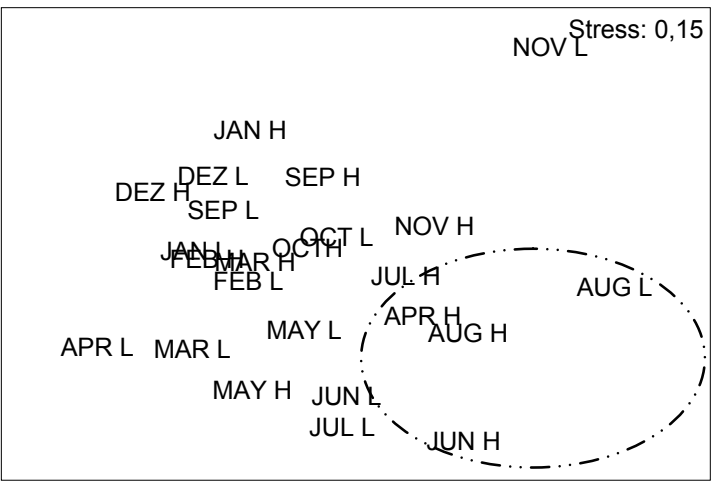

Fig. 3. Non-Metric Dimensional Scaling - MDS Ordination method (Bray Curtis's coefficient) based on CPUE data (individuals/haul) of the main species at Praia dos Anjos beach at low and high tides (September/01 to August/02).

Table 2. Total number of individuals (n) and weight ( $\mathrm{g}$ ) of fish species in Praia Grande beach in low and high tide (September/01 to August/02).

\begin{tabular}{lcccc}
\hline \hline Species & Low tide $(\mathbf{n})$ & Low tide $(\mathbf{g})$ & High tide (n) & High tide (g) \\
\hline Zapteryx brevirostris & 03 & 855.2 & - & - \\
Harengula clupeola & 286 & 965.7 & 443 & 3076.7 \\
Sardinella janeiro & 50 & 137.2 & 125 & 896.3 \\
Prionotus punctatus & 02 & 253.2 & 03 & 1022.7 \\
Dactylopterus volitans & 606 & 3108.4 & 03 & 17.9 \\
Pomatomus saltatrix & 227 & 1348.9 & 31 & 250.6 \\
Caranx latus & - & - & 20 & 205.9 \\
Selene vomer & - & - & 01 & 1.1 \\
Trachinotus carolinus & 171 & 525.0 & 419 & 1324.9 \\
Trachinotus falcatus & - & - & 3 & 3.4 \\
Eucinostomus argenteus & 33 & 285.8 & 177 & 1638.6 \\
Diapterus rhombeus & - & - & 02 & 168.8 \\
Diplodus argenteus & 24 & 458.4 & 112 & 969.3 \\
Menticirrhus americanus & 01 & 2.6 & - & - \\
Menticirrhus littoralis & 01 & 5.7 & 01 & 3.7 \\
Umbrina coroides & 13 & 340.6 & 05 & 49.8 \\
Percophis brasiliensis & 01 & 321.8 & - & - \\
Mugil curema & 02 & 99.2 & 02 & 174.6 \\
Mugil liza & 05 & 607.0 & 01 & - \\
Mugil platanus & 02 & 152.3 & - & 12.8 \\
Citharichthys arenaceus & 01 & 42.7 & 01 & - \\
Symphurus papillosum & 01 & 285.6 & - & 1.1 \\
Stephanolepis hispidus & - & - & 01 & $\mathbf{1 0 3 1 8 g}$ \\
Total & $\mathbf{1 4 2 9}$ & $\mathbf{9 7 9 5 \mathbf { g }}$ & $\mathbf{1 3 5 0}$ & \\
\hline
\end{tabular}


Catches at low tide had a total of $9795.3 \mathrm{~g}$, with $70.3 \%(6885.1 \mathrm{~g})$ corresponding to the biomass of five species: $D$. volitans $(31.7 \%), P$. saltatrix (13.8\%), H. clupeola (9.9\%), Zapteryx brevirostris $(8.7 \%)$ and Mugil liza (6.2\%). It is important to emphasize that the great number of $D$. volitans $(\mathrm{N}=$ 606 individuals) occurred only in February.

Captures during high tide totalled 18 species, which corresponded to $48 \%$ of the individuals and $61 \%$ of the biomass (Table 2); five species were exclusive $(27 \%)$. The families Carangidae (three species), Sciaenidae, Clupeidae and Mugilidae (two species each) presented a higher number of species. $H$. clupeola $(32.8 \%)$, T. carolinus $(31.1 \%)$, E. argenteus (13.1\%), S. janeiro $(9.3 \%)$ and Diplodus argenteus (8.3\%) were responsible for $94.6 \%$ (1276 individuals) of the total number (1350 individuals). The five most representative species related to biomass were Harengula clupeola (29.8\%), E. argenteus (15.9\%), T. carolinus (12.8\%), Prionotus punctatus $(9.9 \%)$ and Diplodus argenteus $(9.4 \%)$, representing $77.8 \%$ (8032 g) of the total (10318 g).

A higher number of species was generally observed at high tides but without significant differences. A similar temporal pattern was recorded for both periods, with a tendency for higher values mainly during the summer months and in July/02 (Fig. 4a). For CPUE (inds/hauls) a similar temporal variation was observed for both tides, with higher values in February/02 and July/02 (Fig. 4b). In relation to CPUE (g/haul), a similar temporal pattern was observed for both tides with higher values in general during the high one, especially in February, April and July/02 (Fig. 4c).

Richness index, species diversity and dominance showed a similar temporal pattern in both periods, with higher values mainly in summer and in July-August/02 during high tides (Fig. 4d, 4e, 4f) with no significant differences between tides.

At Praia Grande Beach, the high dispersion of the months and tides in the ordination analysis MDS corresponded to no tidal or seasonal pattern. The stress value of 0.12 (intermediary) indicates that the similarities are adequately represented by the distances in the chart (Fig. 5). The ANOSIM test could not be done due to the absence of groups by MDS analysis.

\section{Prainha Beach}

During low tides 41 species were collected, which contributed with $59.2 \%$ of the total individuals and $48.4 \%$ of biomass (Table 3 ); 11 species were exclusive (27\%). At low tide, the most representative families were Carangidae (seven species), Sciaenidae (five species), Clupeidae and Haemulidae (three species each). The species with higher catches during low tide were Trachinotus carolinus (39.6\%),
Harengula clupeola (21.3\%), Diplodus argenteus $(10.6 \%), T$. goodei $(7.7 \%)$ and Sardinella janeiro (6.5\%), representing $85.8 \%$ (7524 individuals) of the total. The other 36 species corresponded to $14.2 \%$ (1.248 individuals). In relation to biomass, the dominant species T. carolinus $(22.6 \%), T$. goodei (20.7\%), H. clupeola (17.9\%), S. janeiro (8.6\%), and Mugil curema (5.3\%), totalled $75 \%$ of $46198 \mathrm{~g}$ captured. The remaining species (36) represented $25 \%$ $(15399 \mathrm{~g})$. Table III lists all the species captured during both tides.

During high tides 34 species were collected, which contributed with $40.8 \%$ of the total individuals and $51.6 \%$ of the biomass (Table 3 ); four species were exclusive $(12 \%)$. The most representative families were Carangidae (five species), Sciaenidae (four species), Mugilidae and Pomadasyidae (three species each). The highest captures were for $T$. carolinus (42.1\%), S. janeiro (23.2\%), H. clupeola (10.5\%), $T$. goodei (7.4\%) and Dactylopterus volitans (4.3\%), corresponding to $87.5 \%$ (5297 individuals) of total capture (6054 individuals). The 29 remaining species represented $12.5 \%$ (757 individuals). The total biomass was $54759 \mathrm{~g}$ with $S$. janeiro $(35.2 \%), T$. carolinus (18.8\%), T. goodei (14.4\%), Orthopristis ruber $(8.7 \%)$ and $H$. clupeola $(6.5 \%)$ representing $83.5 \%$ of total capture $(65517 \mathrm{~g})$.

A similar temporal pattern was recorded in the average number of species during both tides with higher values in summer and winter months. No significant differences were observed during both periods except in December/01 $(p \leq 0.05)$, with three times higher value during low tide (Fig. 6a). The CPUE (ind/hauls) revealed a similar temporal pattern for both tides, with higher values mainly in December/01 (low tide) and June/July/02 (both tides). The largest differences between tides were in December/01 (statistically $p \leq 0.05$ ), due to the great number of Diplodus argenteus, Sardinella janeiro and Trachinotus carolinus (Fig. 6b). The CPUE (g/hauls) showed higher values during high tide, mainly in December/01 and June/02, due to Sardinella janeiro. Significant differences between both tide periods were recorded in December $(p \leq 0.05)$ (Fig. 6c).

Margalef's richness was higher during low tide with significant differences $(p \leq 0.05)$ in December (Fig. 6d). Both periods presented a similar temporal variation with higher values in February, March and April/02. Diversity showed significant difference $(p \leq 0.05)$ between tides in December/01. Both presented a similar temporal variation with a higher diversity in the summer and April/02 (Fig. 6e). The dominance showed a similar temporal variation between tides with higher values at high tide (Fig. 6f), although without significant differences $(p \leq 0.05)$. 
a

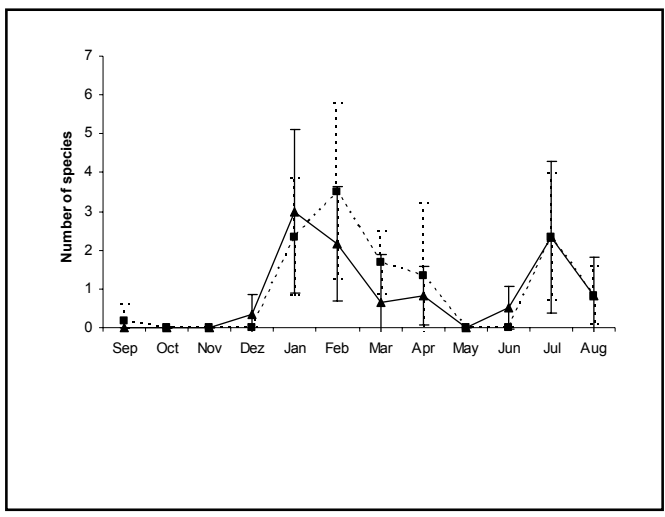

c

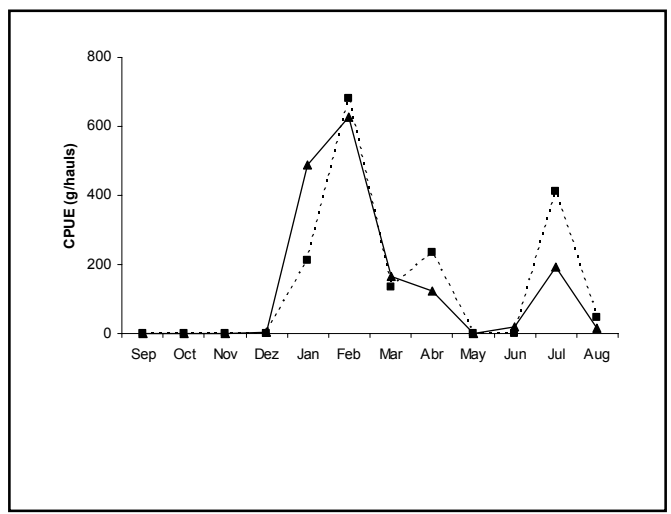

e

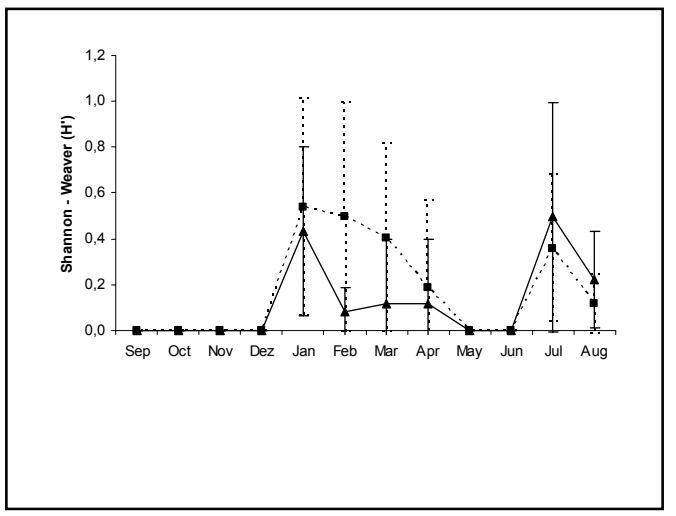

b

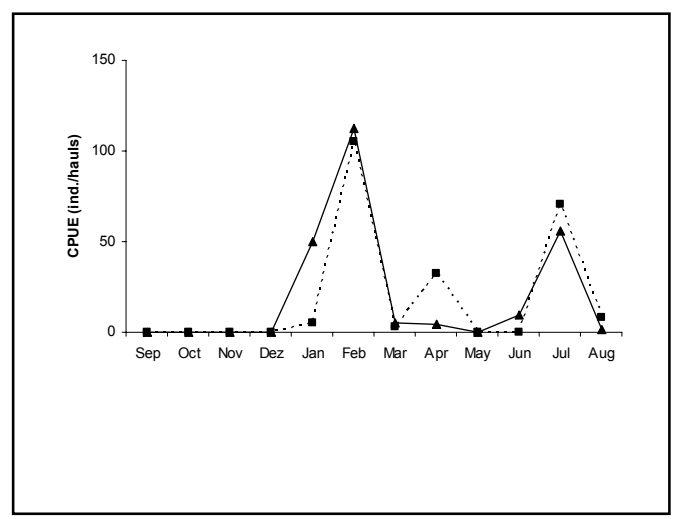

d

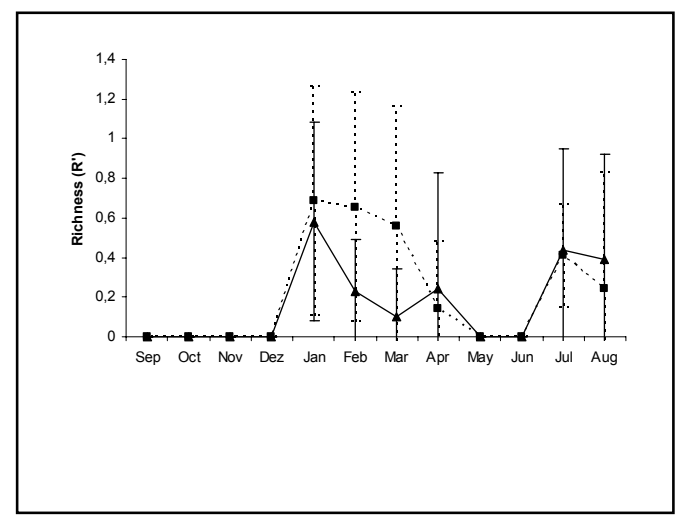

f

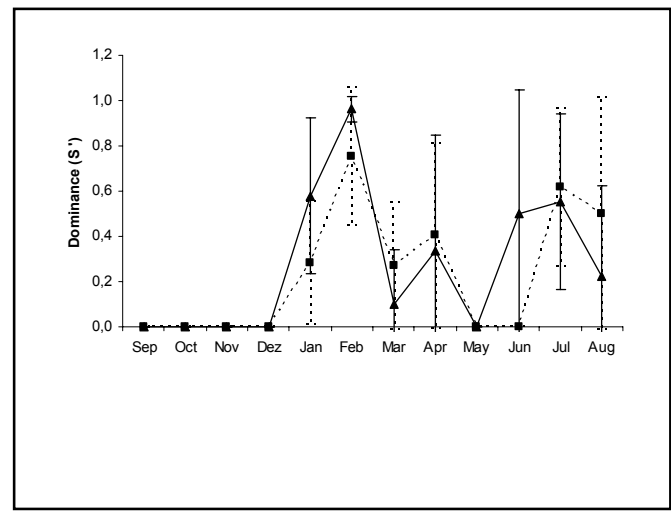

Fig. 4. Temporal variation of average species numbers (a), CPUE ((individuals/haul) (b), CPUE (grams/haul) (c), Margalef's richness (d), Shannon's diversity (e) and Simpson's dominance (f) at low ( $\boldsymbol{\Delta})$ and high ( $\boldsymbol{\square})$ tides at Praia Grande beach (September/01 to Agust/02). 


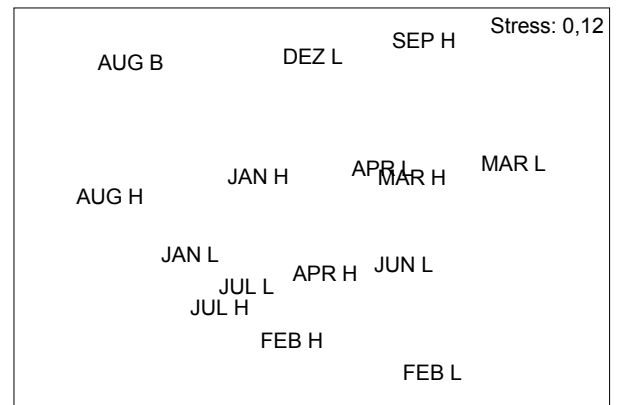

Fig. 5. Non-Metric Dimensional Scaling - MDS Ordination method (Bray Curtis's coefficient) based on CPUE data (individuals/haul) of the main species at Praia dos Grande beach at low and high tides (September/01 to August/02). The periods from September to December/01 and May to June/02 of both tides were not included due to the absence of captured individuals.

Table 3. Total number of individuals (n) and weight (g) of fish species in Prainha beach in low and high tide (September/01 to August/02).

\begin{tabular}{|c|c|c|c|c|}
\hline Species & Low tide (n) & Low tide (g) & High tide (n) & High tide (g) \\
\hline Narcine brasiliensis & 01 & 42.9 & 01 & 51.3 \\
\hline Discopyge tschuddi & 01 & 57.7 & - & - \\
\hline Elops saurus & - & - & 01 & 141.8 \\
\hline Albula vulpes & 02 & 9.0 & 01 & 12.3 \\
\hline Opisthonema oglinum & 05 & 29,4 & - & - \\
\hline Harengula clupeola & 1869 & 10999.3 & 637 & 4230.4 \\
\hline Sardinella janeiro & 570 & 5276.1 & 1403 & 23058.3 \\
\hline Synodus intermedius & 01 & 61.6 & - & - \\
\hline Polydactylus oligodon & 60 & 388.6 & 26 & 479.3 \\
\hline Strongylura timucu & 01 & 54.7 & 01 & 227.3 \\
\hline Atherinella brasiliensis & 01 & 12.9 & 01 & 7.2 \\
\hline Odontesthes bonariensis & 24 & 76.2 & 01 & 1.9 \\
\hline Sygnathus sp & - & - & 01 & 0.2 \\
\hline Prionotus punctatus & 02 & 7.0 & - & - \\
\hline Dactylopterus volitans & 272 & 2885.5 & 259 & 2213.3 \\
\hline Priacanthus cruentatus & 03 & 64.4 & - & - \\
\hline Pomatomus saltatrix & 188 & 1576.1 & 162 & 2072.0 \\
\hline Echeneis naucrates & - & - & 01 & 68.1 \\
\hline Caranx latus & 112 & 1445.0 & 44 & 594.9 \\
\hline Chloroscombrus chrysurus & 01 & 42.4 & - & - \\
\hline Oligoplites saurus & 17 & 727.9 & - & - \\
\hline Selene vomer & 14 & 49.2 & 29 & 223.8 \\
\hline Trachinotus carolinus & 3478 & 13904.1 & 2549 & 12341.6 \\
\hline Trachinotus falcatus & 46 & 249.1 & 59 & 223.2 \\
\hline Trachinotus goodei & 676 & 12770.1 & 449 & 9450.2 \\
\hline Lobotes surinamensis & 01 & 12.8 & - & - \\
\hline Boridia grossidens & 09 & 7.2 & 09 & 82.2 \\
\hline Orthopristis ruber & 14 & 1127.8 & 46 & 5678.8 \\
\hline Conodon nobilis & 06 & 46.8 & 10 & 105.9 \\
\hline Eucinostomus argenteus & 38 & 859.6 & 45 & 969.2 \\
\hline Diplodus argenteus & 930 & 1065.5 & 79 & 238.2 \\
\hline Menticirrhus americanus & 20 & 262.4 & 09 & 101.1 \\
\hline Menticirrhus littoralis & 71 & 1302.5 & 76 & 930.0 \\
\hline Umbrina coroides & 209 & 752.6 & 88 & 1096.8 \\
\hline Stellifer brasiliensis & 09 & 131.6 & 05 & 40.6 \\
\hline Ophioscion punctatissimus & 01 & 14.0 & - & - \\
\hline Pseudupeneus maculatus & 01 & 15.9 & - & - \\
\hline Chaetodipterus faber & 22 & 135.1 & 09 & 34.5 \\
\hline Mugil curema & 48 & 3249.0 & 04 & 545.5 \\
\hline Mugil liza & 07 & 343.7 & 01 & 20.2 \\
\hline Mugil platanus & - & - & 01 & 63.3 \\
\hline Astroscopus ygraecum & 04 & 64.6 & 02 & 32.0 \\
\hline Citharichthys macrops & 01 & 7.7 & - & - \\
\hline Stephanolepis hispidus & 04 & 4.5 & 18 & 27.2 \\
\hline Cyclichthys spinosus & 43 & 300.9 & 27 & 154.2 \\
\hline Total & 8772 & $61597 \mathrm{~g}$ & 6055 & $65517 \mathrm{~g}$ \\
\hline
\end{tabular}


a

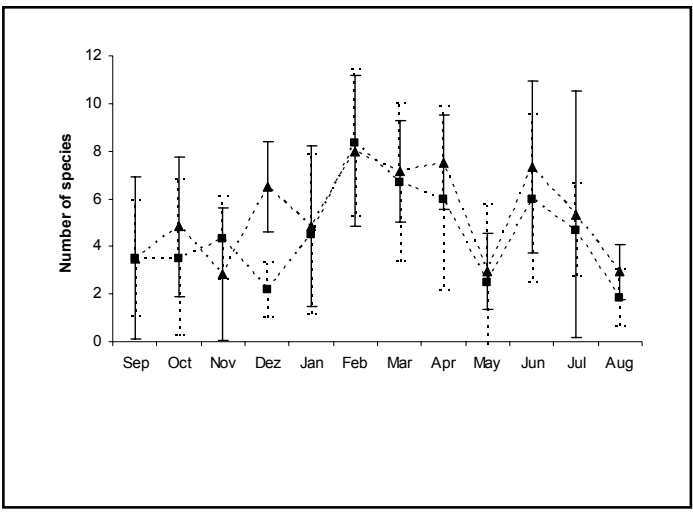

c

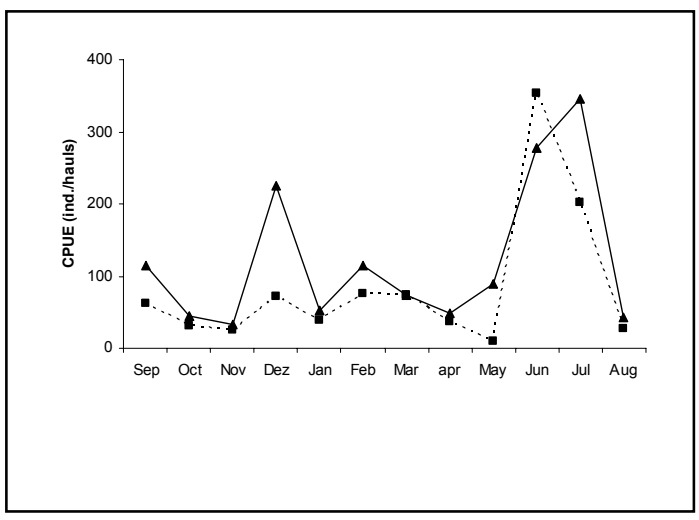

e

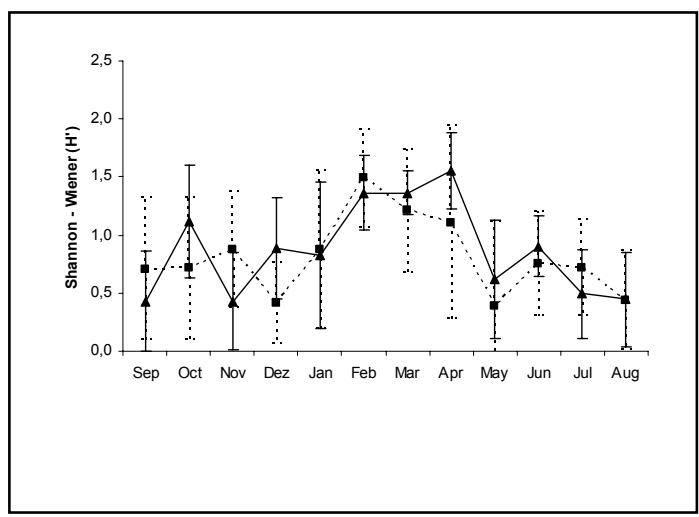

$\mathrm{b}$

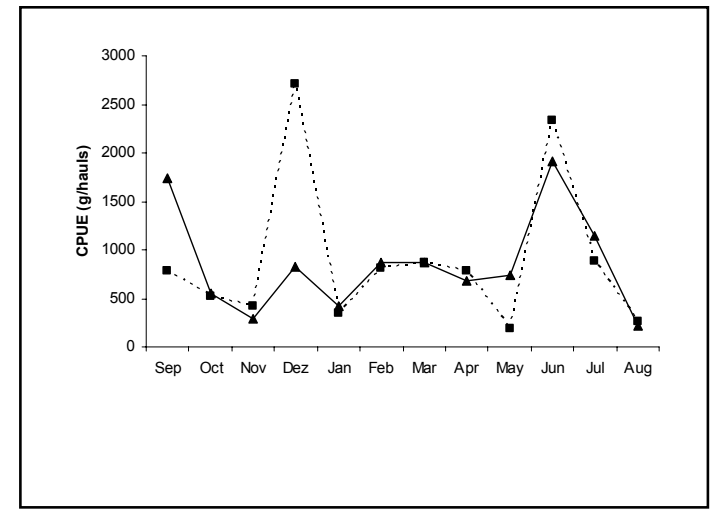

d

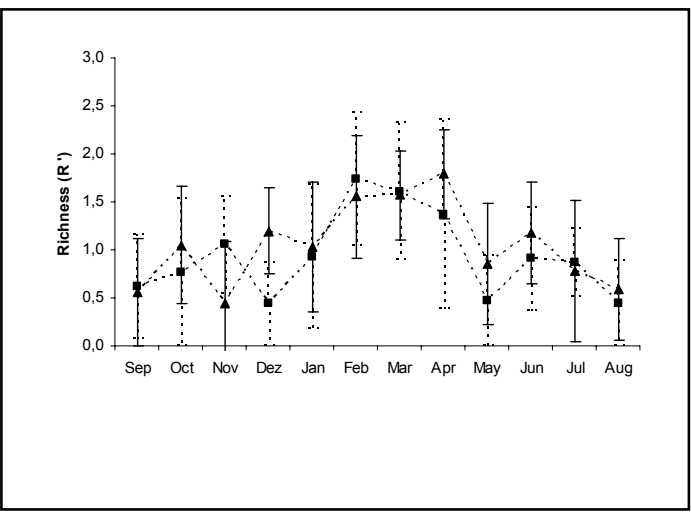

f

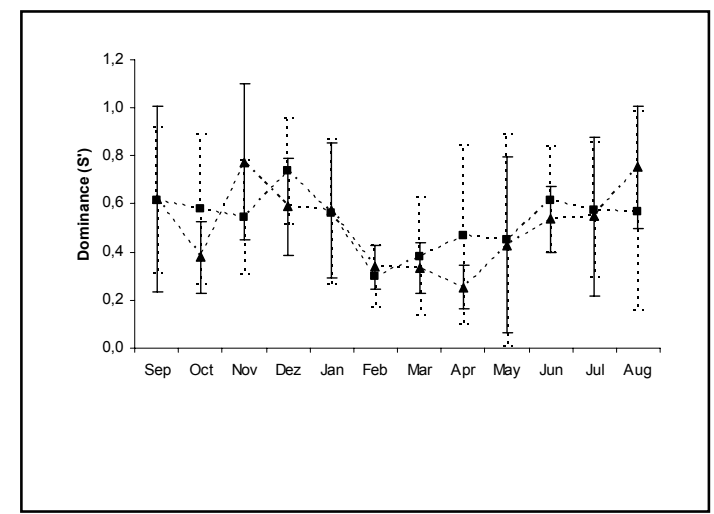

Fig. 6. Temporal variation of average species numbers (a), CPUE (individuals/haul) (b), CPUE (grams/haul) (c), Margalef's richness (d), Shannon's diversity (e) and Simpson's dominance (f) at low ( $\mathbf{\Lambda}$ ) and high (-) tides at Prainha beach (September/01 to Agust/02). 
The ordination analysis MDS in Prainha Beach did not reveal the formation of main groups related to tide levels (Fig. 7), but it showed a real grouping tendency by season (e.g. December-January; March to April; June-July; August to November). The stress value of 0.18 , indicates that the similarities are adequately represented by the distances in the chart (Fig. 7). The ANOSIM showed a significant difference between the groups ( $\mathrm{R}=0.79$, $\mathrm{p}: 0.1 \%$ ).

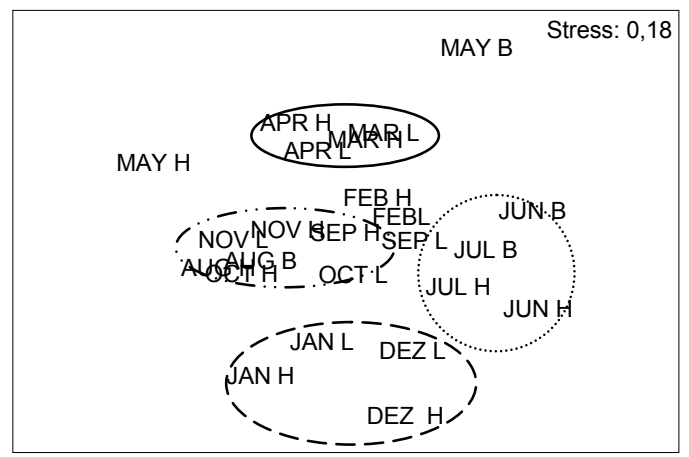

Fig. 7. Non-Metric Dimensional Scaling - MDS Ordination method (Bray Curtis's coefficient) based on CPUE data (individuals/haul) of the main species at Prainha beach at low and high tides (September/01 to August/02).

\section{Discussion}

The surf zone fish community of Arraial do Cabo is characterized by a few dominant species, as seen in several previous studies of sandy beaches (HORN, 1980; ROSS et al., 1987; GIBSON et al., 1993, 1996). The temporal variation of the local ichthyic community derives mainly from changes in the distribution and abundance of such dominant species.

Regardless of the sampled beach, the species were generally common to both tides. A total of $37 \%$ of species occurred exclusively during a certain period, with $70 \%(\mathrm{~N}=16 \mathrm{spp})$ at low tide and $30 \%$ at high tide $(\mathrm{N}=7 \mathrm{spp})$.

At Praia Grande and Prainha Beaches, a higher number of species and individuals were captured during the low tide, as registered for surf zone fish by Lasiak (1984a, 1984b), Whitfield (1989) and Gibson et al. (1996). These authors suggest that generally the hauls at high tides catch species migrating with the tide to the beach. Different results were obtained by Layman (2000) on the Virginia coast, who observed a higher richness at high tide, due to the presence of a great number of transitory adult species. However Senta and Kinoshita (1985) in Tosa Bay, Japan, did not record any tendency in species richness and abundance of juvenile and larval community related to tidal variation.

In relation to biomass, the CPUE at two of the studied beaches, Praia Grande and Prainha, was higher at high tide, indicating a movement of several benthivorous (T. carolinus, T. goodei, Orthopristis ruber and Umbrina coroides) and piscivorous species (mainly Pomatomus saltatrix) to the intertidal zone during this period, probably due to greater food availability (BROWN; MCLACHLAN, 1990; GIBSON et al., 1996; LAYMAN, 2000). High tides allow larger or adult fishes to move towards shallower sites on the beaches with invertebrate abundance in the intertidal zone, which is an unaccessible area to other fish (BROWN; MCLACHLAN, 1990).

In some sandy beach ecosystems, there is a stronger influence of the tide with a higher number of species and individuals during low tide and higher abundance of dominant species and biomass at high tide (LASIAK, 1984b, GIBSON et al., 1993, 1996; SUDA et al. 2002; MORRISON et al., 2002). According to these authors, fish are more concentrated in the surf zone during low tide increasing the number of individuals captured. A lower biomass occurs due to the presence of big schools of juvenile fish. However, at high tide fish are dispersed through a larger area, making their capture more difficult. The migration of bigger individuals to this shallow area is responsible for elevated biomass, due to higher food availability.

In relation to community structure descriptors such as richness, diversity and species dominance, no pattern was observed related to tidal variation at the studied beaches with very similar values during both periods. It is important to highlight that the highest richness and diversity values in the summer months possibly be due to the influx of juveniles, since the majority of the juvenile species use the surf zone during this seasonal period, migrating afterwards to deeper waters (MODDE; ROSS, 1981; PETERS; NELSON, 1987; LASIAK, 1984b; CLARK et al., 1996, GODEFROID, 1997, 1998; LAYMAN, 2000).

The absence of distinct fish groups that may suggest a different ichthyc assemblage at low and high tides agrees with Gibson et al. (1996), Layman (2000) and Pessanha et al. (2003). The abundance of relatively rare species might influence the absence of such well defined groups; yet, as observed in the present study, the main structural changes are due to the variability of the most common species (ROMER, 1990; GIBSON et al., 1996).

At Praia dos Anjos Beach the species richness, individuals number and biomass were higher during low tide and contrasted with the majority of the studies mentioned above. It is suggested that due to its reflective morphodynamic characteristics and small 
post-beach, fish are concentrated in the shallow zone during low tide. Since this beach is not characterized as an exposed one regarding to wave action (CLARK, 1996) and has a small extension of sand, the edge remains deeper and retains fish. Local pollution by domestic sewer is another factor that must be considered. During high tides, the nutrient concentration from the sewage is diluted, while at low tide it is restricted to shallow zones, causing an increase in species number and their abundance (SMITH et al., 1999).

At Prainha Beach, it is suggested that the higher number of species and individuals during low tide, and biomass on high tide is due to the beach morphodynamics with intermediate characteristics and low wave exposure. This facilitates fish migration during high tide. It is also important to mention that during low tide, fish are concentrated near algae beds and/or detached algae, allowing the high capture of young individuals, which feed and look for shelter there. During high tide, the bigger fish come close to shallower zones due to the great availability of food in the macroalgae beds (GRAY et al., 1998; GAELZER; ZALMON, 2003).

At Praia Grande Beach the intertidal zone extension is larger than in the two other beaches, due to the dissipative morphodynamic characteristics and a very large post-beach; the low tide area is more extensive and shallower. Consequently, the elevation of water temperature makes the upwelling effect smaller during this tidal period, causing a higher number of species and individuals, mainly juveniles. During high tides, the effect of the upwelling is more intense with colder water, reflecting in lower density and a higher biomass due to the larger predator species (WILBER et al., 2003).

The structure of the surf zone fish community at Prainha, Praia Grande and Praia dos Anjos beaches was similar according to the tide, differing in relation to the fish biomass, which was higher during high tide just in the latter. Also, the number of individuals, species richness and diversity was higher during low tide, due to the abundance of juveniles, differing from the initial proposal.

\section{REFERENCES}

BENNETT, B. A.; ATTWOOD, C. G. Shore-angling catches in the De Hoop Nature Reserve, South Africa and further evidences for the protective value of marine reserves. $\mathbf{S}$. Afr. J. mar Sci., v. 13, p. 213-222, 1993.

BROWN, A. C.; McLACHLAN, A. Ecology of sandy shores. Amsterdam: Elsevier, 1990. 328 p.

BURROWS, M. T.; GIBSON, R. N.; ROBB, L.; CONNELY, C. A. Temporal patterns of movement in juvenile flatfishes and their predators: underwater television observations. J. exp.mar.Biol. Ecol., v. 177, p. 251-268, 1994.
CERVIGÓN, F. FAO Field guide to the commercial marine and brackish-water resources of the northern coast of south América. Roma: FAO, 1993. 586 p.

CLARK, B. M.; BENNETT, S. J.; LAMBERTH, S. J. Temporal variations in surf zone fish assemblages from False Bay, South África. Mar. Ecol. Prog. Ser., v. 131, p. 35-47, 1996.

CLARKE; K. R.;WARWICK, R. M. Change in marine communities: an approach to statistical analysis and interpretation. Plymouth Marine Laboratory, Plymouth, 2001. 859p.

FIGUEIREDO, J. L.; MENEZES, N. A. Manual de peixes marinhos do sudeste do Brasil, II. Teleostei (1). São Paulo: Museu de Zoologia da Universidade de São Paulo, 1978. $110 \mathrm{p}$.

FIGUEIREDO, J. L.; MENEZES, N. A. Manual de peixes marinhos do sudeste do Brasil, II. Teleostei (2). São Paulo, Museu de Zoologia da Universidade de São Paulo, 1980.90 p.

FIGUEIREDO, J. L.; MENEZES, N. A. Manual de peixes marinhos do sudeste do Brasil, II. Teleostei (5). São Paulo, Museu de Zoologia da Universidade de São Paulo, 2000. 116 p.

GAELZER, L. R.; ZALMON, I. R. The Influence of wave gradient on the ichthyofauna of Southeastern Brazil: focusing the community structure in surf-zone. J. coast. Res., v. 35, p. 456-462, 2003.

GAELZER, L. R.; ZALMON, I. R. Surf-zone ichthyofauna diel variation in Arraial do Cabo, southeastern Brazil. J. coast. Res., SI39, p. 1114-1117, 2006.

GIBSON, R. N.; ROBB, L.; ANSELL, A. D. Seasonal and annual variatons in abundance and species composition of fish and macrocrustacean communities on a Scottish sandy beach. Mar. Ecol. Prog. Ser., v. 98, p. 89-105, 1993.

GIBSON, R. N.; ROBB, L.; BURROWS, M. T.; ANSELL, A. D. Tidal, diel and longer term changes in the distribution of fishes on a Scottish sandy beach. Mar. Ecol. Prog. Ser., v. 130, p. 1-17, 1996.

GIBSON, R. N.; PIHL, L.; BURROWS, M. T.; MODIN, J.; WENNHAGE, H.; NICKELL, L. A. Diel movements of juvenile plaice Pleuronectes platessa in relation to predators, competitors food availability and abiotic factors on a microtidal nursery ground. Mar. Ecol. Prog. Ser., v. 165 , p. $145-159,1998$.

GODEFROID, R. S.; HOFSTAETTER, M.; SPACH, H. L. Structure of the fish assemblage in the surf zone of the beach at Pontal do Sul, Paraná. Nerítica, v. 11, p. 77-93, 1997.

GODEFROID, R. S.; HOFSTAETTER, M.; SPACH, H. L. Moon, Tidal and diel influences on catch composition of fishes in the surf zone of Pontal do Sul beach, Paraná. Revta bras. Zool., v. 15, n. 3, p. 697701, 1998.

GRAY, C. A.; CHICK, R. C.; McElLIGOTT, D. J. Diel changes in assemblages of fishes associated with shallow seagrass and bare sand. Estuar. coast. Shelf Sci., v. 46, p. 849-859, 1998.

HORN, M. H. Diel seasonal variation in abundance and diversity of shallow-water fish populations in Morro Bay, Califórnia. Fish. Bull., v. 78, n. 3, p. 759-770, 1980. 
LASIAK, T. A. Structural aspects of the surf zone fish assemblage at King's Beach, Algoa Bay, South Africa: Long - term fluctuations. Estuar. coast. Shelf Sci.,v.18, n. 4, p. $459-483,1984 a$.

LASIAK, T. A. Structural aspects of the surf zone fish assemblage at King's Beach, Algoa Bay, South Africa: Short - term fluctuations. Estuar. coast. Shelf Sci., v. 18, n. 4 , p. $347-360,1984$ b.

LAYMAN, C. A. Fish assemblage structure of the shallow ocean surf-zone on the eastern shore of Virginia Barrier Islands. Estuar. coast. Shelf Sci., v. 51, n. 2. p. 201213, 2000.

MARGALEF, R. Ecologia. Barcelona: Ediciones Omega, 1986. $951 \mathrm{p}$.

MENEZES, N. A.; FIGUEIREDO, J. L. Manual de peixes marinhos do sudeste do Brasil, II. Teleostei (3). São Paulo: Museu de Zoologia da Universidade de São Paulo, 1980. 96 p.

MENEZES, N.A.; FIGUEIREDO, J. L. Manual de peixes marinhos do sudeste do Brasil, II. Teleostei (4). São Paulo, Museu de Zoologia da Universidade de São Paulo, 1985. 105 p.

MODDE, T.; ROSS, S. T. Seasonality of fishes occupying a surf zone habitat in the northern Gulf of México. Fish. Bull. natn. mar. Fish. Serv., U.S., v. 78, n. 4, p. 911922, 1981.

MORRISON, M. A.; FRANCIS, B. W.; HARTILL, B. W.; PARKINSON, D. M. Diurnal and tidal variation in the abundance of the fish fauna of a temperate tidal mudflat. Estuar. coast. Shelf Sci., v. 54, p. 793-807, 2002.

MUNIZ, P. 2003. Comunidades macrobênticos como indicadoras da qualidade ambiental de ecossistemas costeiros rasos - Estudo de caso: Enseada de Ubatuba (SP, Brasil). Tese ( Doutorado). 224 p. Universidade de São Paulo, 2003.

PESSANHA, A. L. M.; ARAÚJO, F. G.; AZEVEDO, M. C. C.; GOMES, I. D. Diel and seasonal changes in the distribuition of fish on a southeast Brazil sandy beach. Mar. Biol., v. 143, p. 1047-1055, 2003.

PETERS, D. J.; NELSON, W.G. The seasonality and spatial patterns of juvenile surf zone fishes of the Florida east coast. Fla Sci., v. 50, n.2, p.85-99, 1987.

POLUNIN, N. V. C.; ROBERTS, C. M. Greater biomass and value of target coral-reef fishes in two small Caribean marine reserves. Mar. Ecol. Prog. Ser., v. 100, p. $167-$ 176, 1993.
ROMER, G. S. Surf zone fish community and species response to wave energy gradient. J. Fish Biol., v. 36, p. 279-287, 1990.

ROSS, S. T.; MCMICHAEL, R. H.; RUPLE, D. L. Seasonal and diet variation in the standing crop of fishes and macroinvertebrates from a Gulf of Mexico surf zone. Estuar. coast. Shelf Sci., v. 25, p. 391-412, 1987.

SENTA, T.; KINOSHITA, I. Larval and juvenile fishes occurring in surf zones of western Japan. Trans. Am. Fish. Soc., v. 114, p. 609-618, 1985.

SMITH, A. K.; AJANI, P. A.; ROBERTS, D. E. Spatial and temporal variation in fish assemblages exposed to sewage and implications for management. Mar. environ. Res., v. 47, p. 241-260, 1999.

SUDA, Y.; INOUE, T.; UCHIDA, H. Fish communities in the surf zone of a protected sandy beach at Doigahama, Yamaguchi Prefecture, Japan. Estuar. coast. Shelf Sci., v. 55, p. 81-96, 2002.

VALENTIN, J. L. Analyse des paramèters hydrobiologiques dans la remontée de Cabo Frio (Brésil). Mar. Biol., v. 82, p. 259-276, 1984.

WILBER, D. H.; CLARKE, D.G.; BURLAS, RUBEN,; WILL, R. J. Spatial and temporal variability in surf zone fish assemblages on the coast of northern New Jersey. Estuar. coast. Shelf Sci., 56:291-304, 2003.

WHITFIELD, A. K. Ichthyoplankton in a southern African surf zone: Nursery area the postlarvae of estuarine associated fish species? Estuar. coast. Shelf Sci., v. 29, p. $533-547,1989$.

YONESHIGUE, Y. Taxonomie et ecologie des algues dans la région de Cabo Frio (RJ), Brésil. These (Doct. Sci.). 466 p. Fac. Luminy. Univ. Aix-Marseille II, 1985.

(Manuscript received 09 June 2006; revised 04 January 2007; accepted 09 August 2007) 